\title{
ADEMIA: AGAMBEN AND THE IDEA OF THE PEOPLE
}

\begin{abstract}
It is in the retrospective effect of the nonexistence of a state that the "people" can be part of the naming of a political process and thus become a political category. As soon as the state in question is formed, regulated, and enrolled in the "international community", the people it claims as its authority ceases to be a political subject. It becomes a passive mass that the state configures, universally, no matter what the form of the state.
\end{abstract}

Alain Badiou ${ }^{1}$

\begin{abstract}
In the volume Stasis. Civil War as a Political Paradigm, the Italian philosopher Giorgio Agamben advances the thesis that ademia - the absence of a people (a-demos) - is a constitutive element of the modern state. When confronted with the fact that modern political and juridical thought elevated the people to the role of the sole chief constituent agent and the ultimate source of the legitimacy of constituted orders, this thesis turns out to be rather problematic. In this work, I will explore Agamben's notion of ademia, retracing the main lines of its theoretical development and reconsidering it in relation to different interpretations of the idea of the people. Most notably, I will demonstrate how Jean-Jacques Rousseau and Carl Schmitt in challenging the conundrums that the idea of the people inevitably entails ended up in revealing the ultimate absence of the people in the political space of the constituted order of the state. In doing so, I will try to show how Agamben's notion of ademia is helpful is grasping some of the main paradoxes and conundrums underpinning the meaning and the uses of the idea of the people in legal and political thought.
\end{abstract}

Keywords: Agamben, Ademia, People, Multitude, Rousseau, Schmitt.

\section{INTRODUCTION}

In the volume Stasis. Civil War as a Political Paradigm, the Italian philosopher Giorgio Agamben advances the thesis that ademia - the absence of a people (a-demos) - is a constitutive element of the modern state (Agamben 2015). When confronted with the fact that modern political and juridical thought elevated the people to the role of the sole chief constituent agent and the ultimate source of the legitimacy of constituted orders, this thesis turns out to be rather problematic. For modern thought the people has become a linchpin in the composition of

\footnotetext{
"University of Kent; Uczelnia Lazarskiego, g.g.fusco-3@kent.ac.uk

${ }^{1}$ Badiou 2016, 25-26.
} 
state's organisation. One paradigmatic example of this view is the renowned Georg Jellinek's "three elements doctrine" [drei elemente lehre], according to which the people [Staatsvolk], alongside with a defined territory [Staatsgebiet] and the monopoly of state's power (and of the legitimate exercise of violence) [Staatgewalt], is a fundamental element of the state (Jellinek 1914). The essential bond that ties the state with the "people" is even more prominent in democratic constitutionalism, which declaims the unitary subject of the people as the unique, original source of every legitimate constituted power.

Although it might seem counterintuitive, Agamben's hypothesis points to a crucial problem seldom considered by political rhetoric (especially in its more populist version) and by the accepted idea of popular sovereignty, namely the fact that in its very meaning and in its actual existence, the people lacks of an unambiguous stable substance-identity. 'Every interpretation of the political meaning of the term people', Agamben claims, 'must begin with the singular fact that in modern European languages, "people" also always indicates the poor, the disinherited, and the excluded' (Agamben 1998, 176). The people is alternatively 'the constitutive political subject and the class that is, de facto if not de jure, excluded from politics' (Agamben 1998, 176), becoming in this way, the signifier for both the political actor par excellence (the people as the author of the constitution) and the impolitical mass of individuals with their private lives and biological needs.

This semantic ambiguity goes along with a further complication inherent to the doctrine of constituent power. In jurisprudence, constituent power represents the ultimate source of constitutional norms and institutional arrangements. It is configured as 'an all-powerful and expansive power', whose absolute and formless creative potential must be 'reduced to the norm of the production of law' (Negri 1999, 2-3). To function properly as foundational element of legal orders, constituent power has to be put-in-a-form, restrained into an established order, and therefore perverted in its nature. Constituent power, though, exists as long as it is negated; and the people - being the holder of such formless power - after the decisional act of constituting itself in a politically organized community, falls outside the realm of the constituted order. In this sense, the appearance of a constitution corresponds to the oblivion of its author. For these reasons, Agamben maintains that the people 'to the extent that it is the bearer of constituent power must find itself outside all juridical-constitutional normativity' (Agamben 2015, 50). And the state, in electing the people as the source of its own organisation, lives in a constant condition of ademia, while paradoxically being the most proper "realisation" of the people.

This paradox raises inevitably the question of the place and role of the people in relation to its own creation. In Western modern political tradition, the people embody the substance of the community and the object of state's government (Possenti 1988); but, if the subject "people" is systematically excluded from 
the constituted order, the state finds itself de-substantialised. The state in this perspective would be the "pure" form of an absent substance. What is, thus, the subject (and the object) of modern state power, if the people cannot be present inside the boundaries of the constituted order? In Stasis, Agamben (through a reading of Hobbes's distinction between the concepts of "people" and "multitude), provides an answer to this question. The main subject of political power and governmental practices is not "the people", but the impolitical body of a multitude. In the event of the exercise of its faculty of self-constitution, the people loses its political potential, leaving the stage to a "confused" - impolitical - multitude. ${ }^{2}$ Akin to the modern idea of "population", the multitude has not a proper political significance; rather, it represents the sum of passive and docile bodies of the people. ${ }^{3}$

In line with what one could expect from a text of this length, the following pages do not seek to enquiry exhaustively the questions surrounding the ideas of the people. Rather this article is committed to a more modest, but engaging task. I will explore Agamben's notion of ademia, retracing the main lines of its theoretical development and reconsidering it in relation to different interpretations of the idea of the people. Indeed, the peculiar aporia that Agamben poses at the core of the definition of ademia - namely the impossibility for the people of finding a coherent place in its own constituted order - could be encountered in different moments of the evolution of Western political thought and jurisprudence. Most notably, I will demonstrate how Jean-Jacques Rousseau and Carl Schmitt in challenging the conundrums that the idea of the people inevitably entails ended up in revealing the ultimate absence of the people in the political space of the constituted order of the state. ${ }^{4}$

While admittedly quite abstract, Agamben's notion of ademia is indeed helpful to grasp effectively some of the main paradoxes underpinning the meaning and the uses of the idea of the people, which we should not refrain from questioning - especially in a time like the one we are living in. The concept of Ademia conveys openly the impossibility of thinking the people as having an authentic political existence inside the constitutional boundaries of the state. The people is never a natural given that pre-exists the state; rather it is a signature that, on the one hand functions as an element in the dialectic of the foundation upon

\footnotetext{
${ }^{2}$ For a detailed reconstruction of Hobbes' distinction see: Piasentier, Tarizzo 2016.

${ }^{3}$ It must be acknowledged that Agamben's idea of multitude represents an alternative to the "revolutionary" conception of multitude made popular by Negri, Hardt and Virno (See: Negri, Hardt 2004; Virno 2004).

${ }^{4}$ I must specify that this work does not want to be a history of the concepts of ademia and of "people", and for this reason it does claim to adhere to the specific methods of the different strands of the history of ideas. Rather, I aim to test the validity of Agamben's theory, by confronting it with the thought of authors such as Rousseau and Schmitt; and certainly, the list of thinkers who have incurred in the questions raised by the theory of ademia could be longer. The comparative approach, I have chosen, thus, points to find a confirmation of Agamben's theory, rather than establishing a genetic lineage.
} 
which the West thought the legitimacy of its institutions, and on the other hand represents the image (or matrix) orienting - the often tragic - political decision on the limits and forms of political communities.

\section{DIVIDED PEOPLE}

Speculations over the meaning of the word "people" are recurrent in Agamben's oeuvre since, at least, the volume Homo Sacer. Sovereign Power and Bare Life, where he firstly engaged with the ambivalent polysemy of such term. The term "People", Agamben maintains, indicates two substantially opposed entities: "the People" as a political agent and "the people" as the class of individuals whose social, juridical and economic status do not permit them to take part, fully, to the life of a community. Therefore, the semantic sphere of the word people embraces two opposed senses: the People as the source of the legitimacy of legal and political orders represent the counterpart of the people, as those who cannot be part of the political community. What we usually call "people", Agamben points out, is not 'a unitary subject but rather a dialectical oscillation between two opposite poles': the People as a 'whole and as an integral body politic' and the people as a 'subset and as a fragmentary multiplicity of needy and excluded bodies' (Agamben 1998, 176). Therefore, the people are never 'present as a whole' (Agamben 2015, 50) but implicates, logically, a fundamental division, between the whole of the included and the excluded.

In the book The Time That Remains. A Commentary on the Letter to the Romans, Agamben returns over the idea of a "divided people", through a reading of the biblical image of "Israel". In the Jewish biblical tradition, he claims, the 'principle of the law' is 'division' (Agamben 2005, 47). The grounding of Jewish law is made possible only through a clear-cut separation between Jews and nonJews, between Ioudaioi and ethnē. In 'the Bible, the concept of 'people' is in fact always already divided between am and goy'; where 'Am is Israel, the elected people, with whom Yahweh formed a berit, a pact', and the goyim are the other peoples. What marks the establishment of Israel is not the identity of a people with itself, but the fracture, generated by the adhesion to the law, which divides the People and the "peoples" - the Jews and the gentiles. As Leland de la Durantaye maintains, the divided people of Israel, for Agamben, 'becomes a paradigm for the notion that the idea of a people cannot and should not be thought of as pure, whole, or without remainder' (de la Durantaye 2005, 300). The unitary subject of the people, is always the outcome of a division, the remnant of a separation; and the attempt to establish a community through the delimitation of an identity encapsulating the individualities of its member, is made possible through the division itself. The whole of the people, thus, is thinkable only as the reminder of 
a separation; and the concrete determination of the people - established through the adhesion to a law (or a pact) - entails a substantial degree of separation.

The image of a "divided people", in this regard, becomes the cypher of the impossibility of thinking the people as a coherent and homogenous unity, in which every element can be subsumed under a single presupposed identity. The people can never coincide in every single particle with its supposed idea. In its existential dimension, the people, is entrapped in a space marked, on the one side, by the tension between the unity of its political representation and the disunited singularities of its members, on the other side by the opposition to the other, excluded and separated "people".

What is more, the fault line informing the semantic structure of the people, for Agamben reflects the original biopolitical fracture that separate bios and $z o \bar{e}$; the politically qualified life of the "citizens" and all those subjects that are prevented from having a proper position in the polis. In this regard Agamben writes:

there exists no single and compact referent for the term people anywhere: like many fundamental political concepts [...], people is a polar concept that indicates a double movement and a complex relation between two extremes. This also means, however, that the constitution of the human species into a body politic comes into being through a fundamental split and that in the concept of people we can easily recognize the conceptual pair identified [...] as the defining category of the original political structure: naked life (people) and political existence (People), exclusion and inclusion, zoe and bios. The concept of people always already contains within itself the fundamental biopolitical fracture (Agamben 2000, 31-32).

Once again, Agamben portrays the people as oscillating between the two existential forms of a "politically qualified life" (bios - the People) and the impolitical-excluded biological life (zoē). And the unity of a political community becomes possible through this separation. Consequently, a constituted order is the ultimate outcome not of the "will" of founding agent, but of the relation established by the original division of "the people" from its minor counterpart. In this way, Agamben deconstructs one of the symbolic pillars of modern constitutionalism. He puts in question the "people" as a unitary subject, as unique author of the constitutional order; replacing the solid ground of the popular will, with the instability of a relation between two (opposite) terms. If the people are always a reminder of a separation, a constituted order presupposes and, in a way, sustains that very separation - with all the unpredictable, conflicted and "tragic" consequences every separation entail.

But along with the ambivalence between masses positively or negatively valued, the term "people" entails a further semantic ambiguity: the one that separates and distinguishes the people as political creation and as natural or historical datum (Crépon, Cassin, Moatti 2014, 751). And given the role the people play in legal thought, this ambiguity had inevitably a repercussion on the very definition of constitution. From the perspective of constitutional law, Agamben claims, 'on the one hand, the people must already in itself be defined 
by a conscious homogeneity, regardless of what kind (whether ethnic, religious, economic and so on), and hence is always already present to itself; on the other hand, as a political unity it can be present only through those who represent it' (Agamben 2005, 50).

As the author of its own constitution, the people should be present, in the form of a self-conscious unity of subjects - sharing certain a common culture and history - prior to the constitutional act. However, the people become properly "the People", only in the moment of giving itself a constitution; only when represented into a sovereign institution. Thus, Agamben concludes that the people are 'the absolutely present which, as such, can never be present and thus can only be represented' (Agamben 2005, 50). Only when manifested into a mechanism of representation, the people can be thought as a unity. But this logically implies that the people become a decisive political subject only through its institutionalisation and at the cost to disappear.

\section{PEOPLE AND MULTITUDE}

Who is the subject of state's power, if the "people" cannot find an accommodation inside the border of constituted orders? What is the substanceobject of state's sovereign institutions? Agamben offers an answer to these questions through an interpretation of the frontispiece of Hobbes's Leviathan. His exegesis begins by noting that the Leviathan, the 'artificial Man called Commonwealth or State does not dwell within the city', but is placed outside of it. The Leviathan rests beyond the limits of the city and over the territory of his domain; and the body political, consequently, 'does not coincide with the physical body of the city' (Agamben 2015, 34-37). A possible explanation of this paradoxical aspect, Agamben claims, is that 'the population has been fully transferred to the body of the Leviathan', and therefore, 'not only the sovereign' but also the "people" has no place in the city (Agamben 2015, 37).

In the representation of the "physical" and symbolic space of the Hobbesian state, though, the people seem, paradoxically, absent. Agamben finds a solution to this riddle in Hobbes' De Cive, when the English philosopher advanced the fundamental distinction between "people" and "multitude". The people, Hobbes claims

is something single [unum quid], which has one will and to whom one action can be attributed. None of these can be said of the multitude. The people reigns in every city [Populus in omni civitate regnat]; even in a monarchy the people commands, for the people wills by the will of one man. The citizens, that is, the subjects, are the multitude. In a democracy and an aristocracy, the citizens are the multitude; but the council is the people [curia est populus]. And in a monarchy, the subjects are the multitude, and (although this is a paradox [quamquam paradoxum sit]), the king is the people [rex est populus] (Hobbes 1983). 
While supposedly composed of the same substance - the individual existence of the subjects of the "commonwealth" - the people (as rex or as council) differ from the number of single "citizens" composing the multitude. The people acquire a political subjectivity only when represented in the figure of the sovereign (or of the council). Hence, as Agamben put it, the people can be thought as sovereign only 'on the condition of dividing itself, of splitting itself into a multitude and a people' (Agamben 2015, 43). It is as if in the moment of being represented in a sovereign-institutionalised organ (the rex-sovereign or a council) the people leave the stage of politics open to the emergence of the multitude as a primary actor.

Indeed, as Agamben notes, for Hobbes in the act of choosing a sovereign, in the very moment of uniting themselves into the same body-politics, the people dissolves itself 'into a confused multitude' (Agamben 2015, 46). Under the command of the Sovereign, the people 'is no longer one person, but a dissolved multitude [populus non amplius est persona una, sed dissoluta multitudo]' (Agamben 2015, 46). Hobbes's description of the process of constitution of the political body of the state, turns out to be a cycle that connect a "disunited multitude" that pre-exists the covenant and the creation of the community, and the "dissolved multitude" that follows it. The constitution of the populus-rex appears in the exact moment of the decision for the entrance into the covenant, in the point of passage between the disunited and the dissolved multitude. In the Hobbesian interpretation of the emergence of a political body the people are a "People" only in the "event" of constituting itself as 'one Man, or an assembly of men, to beare their Person'; but this very moment represents also the point of oblivion of the people as a political subjectivity. Therefore, the body political, Agamben claims, 'is an impossible concept, which lives only in the tension between the multitude and the populus-rex' (Agamben 2015, 45).

What is more, in Agamben's account, Hobbes's theory of the constitution of the Leviathan represents an early symptom of the modern biopolitical turn of sovereign power. By dividing the people from the multitude, and in defining the latter as the proper subject dwelling the polis, Hobbes shows the awareness of the difference between the political agency of the people and the unpolitical essence of the population; difference that, as Foucault argued, will be fundamental in the emergence of modern biopolitics. ${ }^{5}$ The multitude, in fact, has no political function; the multitude 'is the unpolitical element upon whose exclusion the city is founded' (Agamben 2015, 47), and upon which it is possible to exercise something like a bio-political power.

According to Agamben, the biopolitical significance of Hobbes's multitude, is witnessed also by the symbolism of the Leviathan's frontispiece. ${ }^{6}$ The presence of the 'plague doctors' wearing the 'beaked mask' reminds 'the selection and

\footnotetext{
${ }^{5}$ On this point see: Foucault 2007.

${ }^{6}$ See: Falk 2011.
} 
the exclusion, and the connection between epidemic, health and sovereignty' (Agamben 2015, 48). The multitude, 'like the mass o plague victims' could be 'represented only through the guards who monitor its obedience and the doctors who treat it'; it 'dwells in the city, but only as the object of the duties and concerns of those who exercise the sovereignty' (Agamben 2015, 48).

The impolitical multitude of the disunited individual existences represents the sole actual substance of the state. The constitution of the Leviathan, thus, presupposes a radical form of de-politicisation: the evanescence of the political potential of the people, which is passed in the absolute power of the sovereign. What remains of this process is a multitude: an assemblage of individuals with a strictly biological essence, under the care of sovereign institutions. The multitude, thus, is the un-political side of the people-sovereign; it is what remains when the people has instituted itself.

Here, the care of the multitude has the decisive function of assuring the stability and the continuity of the community. The multitude is always exposed to the risk of dissolution, since it is the locus of the creation of new covenants. It is in fact the "multitude" of men, in the act of constituting itself as a people, the author of the commonwealth. The governmental care of the citizens, which is the supreme aim of sovereign power, is a practice apt to limit the dissolutive forces embodied in the multitude. To govern, though, means to block the cycle of the constitution of the city, to keep at bay the political potential of the "people" as decisive unity.

The endurance of a political community and of the State is conditioned by the necessary removal of its author. It seems, thus, as if once the creational force of the people has been absorbed and instituted, it has to be kept at bay in order to ensure the endurance of the constituted order. With the concept of ademia Agamben exposes this specific removal that stands at the core of the modern conception of the state's form. In this perspective, governmental practices (and more generally institutions) are ultimately operating a limitation of the creational potential of the people.

\section{ROUSSEAU, THE SOCIAL CONTRACT AND THE PEOPLE}

Central to Agamben's concept of ademia is the peculiar fact that the People as the author of state's constitution, does not coincide with the people as the sum of the members of the body-political of the state. He seems to suggest that the legal and political order of the state cannot sustain the presence of its own founding agent. And, in a sense, this is nothing other than a re-formulation of the paradoxical definition of representative government. According to the principle of representation, the political agency of the people becomes manifest only when represented in state's institutions. This logically implies, however that the people are ultimately absent 
from the people's administration. As Bernard Manin argued, in representative democracies the people acquire political agency and capability of self-expression only through the person of the representative' and once authorized, representative bodies replace the represented. The idea of representative government presupposes the presence of a "gap" between who governs and the governed. In representative political systems, Manin points out, who governs 'can never say with complete confidence and certainty "We the people" (Manin 1997, 174-175).

An author who has struggled to overcome the conundrums of representation was certainly Rousseau, whose political imagination strived for making the "sovereign people" present in the stage of the political life of the state (Canovan 2005, 115). For Rousseau, popular sovereignty cannot be expressed and exercised by representative institutions; and the whole apparatus of government is put in motion according to the dictates of the sovereign general will. However, his attempt not to make the people disappear, to some degree failed. In Rousseau's theory of state's organisation, the position and the function of the people seems to incur in contradictions similar to those Agamben has recorded under the definition of ademia.

In the Social Contract Rousseau begins the construction of his theory of the state with the examination of the act 'by which a people become a people that represents the ultimate event of 'foundation of the society' (Rousseau 2002, 162). Antecedent to the institution of a kingdom, a Republic or a political body more in general, there should be an act of constitution of the "people", in the form of a pact. Rousseau summarises this process as follows: 'each of us puts in common his person and all his power under the supreme direction of the general will, and in return each member becomes an indivisible part of the whole' (Rousseau 2002, 162). The volonté générale is supposed to reconcile the necessity of the individuals to perceive the protection of their interest and the need for the preservation of the whole; it is 'directed to the common good and is ideally just', since its 'willed by the people (both as individuals and as a body assembled)' (Canovan 2005, 115).

However, Rousseau seemed conscious of the difficulties entailed in the process of unifying a multitude of different interests towards a general common good (qualitatively different from the sum of the individual interests). The figure of the lawgiver, thus, is 'conjured up', to 'form individual citizens into a cohesive people' (Canovan 2005, 115). 'In order to discover the rules of association that are most suitable to nations', Rousseau writes 'a superior intelligence would be necessary, who could see all the passions of men without experiencing any of them' (Rousseau 2002, 180). The legislator should be an 'extraordinary man' capable 'of changing human nature; of transforming every individual, who in himself is a complete and independent whole, into part of a greater whole' (Rousseau 2002, 180). Rousseau condenses the functions of the legislator in the expression instituer un peuple - to institute a people that is making the people expressing a unitary will. 
In Rousseau's social contract, the entity "people" - as a political category - is entangled in a continuous process of self- constitution: it represents the foundational agent of the state and, at the same time, it is established by the same institution it creates. A people is a 'community of citizens united by a social contract'; it is, therefore, the unity of a plurality capable of expressing a general will. Yet, the legislator is the agent who has the task to establish the general will. The people, in this way, creates its proper institutions to be such; and the original moment of emergence of the general will is brought into the very institutional structure. The people can exercise its deliberative power only as "People"; however, to be the people, the individuals, need to be able to legislate over themselves, that is to say, needs to be (or to have) a legislator capable of cementing the singular into the universal of the general will.

Rather than a given political entity, Rousseau's people can be described, as a "process" of self-constitution in which the creation of legitimate "governmental" and legislative institutions are functional the constitution of the people as such. In this regard, the people become the product of what it is supposed to be its product. Therefore, if the people become such through the establishment of its own institution, that is through the legislator, what is the place of the "people" in Rousseau's theory of the state? Rousseau offer an answer to this question while discussing the general idea of government, in book III of his Social Contract. Every free act, he claims, has

two causes which together produce it; one is moral that is, the will that determines the act; the other is physical, that is, the power that executes it. When I walk toward an object, first I must want to go toward it; in the second place, my feet must take me to it. [...] The body politic has the same driving forces; in it, we discern force and will, the latter under the name of legislative power, the former under the name of executive power. Nothing is, or ought to be, done in it without them (Rousseau 2002, 193).

In this schema the people are present as a "legislative will" and therefore is reduced to the 'moral' source of the 'physical' act of administering the Nation. For Rousseau, thus, the people are the "moral" source of state's institutions and governmental actions. It represents the source of the force animating the life of the body-politics of the state; but concretely, it remains absent in the moving machine for the administration of the res publica.

Rousseau's idea of the state turns out to be a composition of three elements: a sovereign (legislator), a government (magistrate) and the subjects that obey to the law. These three entities have different functions, and their equilibrium is vital for the self-standing of the state: if the sovereign wishes to govern, or if the magistrate wishes to legislate, or if the subjects refuse to obey, disorder prevails over order, force and will no longer act in concert, and the State being dissolved falls into despotism or anarchy'(Rousseau 2002, 194). In this partition the people are ultimately absent. The people $i s$ indeed the sovereign, but only through the 
legislator. Sovereignty, in fact, is 'the exercise of the general will', which is the outcome of the encounter of the unity of the singular interests with a lawgiver. In this schema the people are present only as "the subjects", which is the term Rousseau uses to define the members of the body-political inasmuch 'they are subjected to the laws of the State' (Rousseau 2002, 164), that is when they are passively ruled.

In Rousseau's theory of the state the people (as a political agent) does not have a determined place, other that being the "moral source" of the action of government. And even though he stressed tenaciously the pre-eminence of the general will in the architecture of state's powers, his theory failed in accommodating the political agency of the "people" inside the state. The general will is always mediated by the extraordinary capacity of the legislator; and the people acquire the status of political subject only through its institution. Ademia, consequently, is an element of Rousseau's image of the state.

\section{PEOPLE ANTERIOR TO AND WITHIN THE CONSTITUTION}

In chapter 18 of his Constitutional Theory, Carl Schmitt sums up the meanings of the term people in relation to modern constitutionalism, by distinguish between "unformed" and "formed" people. The "unformed" people (composed by those who are not officials or holder of public functions) stands above the constitutional framework, as the bearer of the constitution-making power and of the public opinion. The "formed" people, instead, is the "people" within the constituted order, implementing its decisional power thorough regulated procedures, such us elections and referendums. With this (qualitative) distinction, Schmitt designates the two main existential dimensions that the people hold in democratic regimes (Schmitt 2008, 279).

In Schmitt's account, Democratic orders are - by definition - the product of an 'act of the constitution making power', which through an autonomous original decision 'determines the entirety of the political unity in regard to its peculiar form of existence'. Therefore, the "people" as the holder of such power pre-exists the decision towards the creation of the constitutional order; and the constitution represents the political form that an already existing people decides to give to itself. "It is not the case that the political unity first arises during the "establishment of a constitution", Schmitt claims, rather "such constitution is a conscious decision, which the political unity reaches for itself' (Schmitt 2008, 75-76). The constitution is, in this perspective, the "form" of the political union that a determinate people - with a given identity and established customs and institutions - decide to assume. As long as the people is what is presupposed by any political and constitutional form, it must be necessarily unformed and "above" the constitutional order. 
The existential dimension of the people as the bearer of the constitutionmaking power is the one that pertain to a formless entity whose self-decisional power is unrestrained and potentially limitless. The people, for Schmitt, much like the sovereign of Political Theology, has the faculty to decide in autonomy the form of its own existence as political community. It is prerogative of the people, to decide which kind of political orders would be most suited in relation to what it is deemed the "normal" framework of its life (Schmitt 2005). For Schmitt constituent power is by definition unlimited and can do whatever it wills: the people in its decisional act is free to give itself an arbitrary constitution.

However, the emergence of a constituted order absorbs and perverts the political potential of the people, channelling it into specific procedural forms, for mediated and to a certain extent, predictable decisions. Inside the boundaries of a constituted legal order, Schmitt claims, the people can execute its decisional function only through "election", "vote" and more generally systems of validation; but this is tantamount to transform the people to the point of making it disappear: in democratic constitutional orders, Schmitt claims, "the people elect and vote no longer as the people' (Schmitt 2008, 273). In the act of taking part to a popular election or a referendum, the citizen is isolated, and the decisional instance of the people is fragmented in many separated individual preferences. For the secret ballot, there is no people, but only citizens with their lives, needs and private interests.

But for Schmitt, it is proper of a democracy to keep the decisional potential of the people intact; it is implicit in the idea of democracy the attempt to make the people present. Following the lesson of (Sieyès 2003), Schmitt sustains that democratic orders are perpetually exposed to the possibility of the actualisation of the people's deciding power. Therefore, Schmitt claims, even though in constitutional regimes the people can legally implement its decisional instances through regulated procedures (elections and voting), its potential for political action and significance in a democracy is in no way exhausted or settled' (Schmitt $2008,271)$. In a democratic order, he writes,

the people continue to exist as an entity that is directly and genuinely present, not mediated by previously defined normative systems, validations, and fictions [...] the fact that individual constitutional powers are assigned to the voters and state citizens entitled to vote still does not transform the people into an administrative organ. It is precisely in a democracy that the people cannot become the administrative apparatus and a mere state "organ." [...] The people in its essence persists as an entity that is unorganized and unformed. (Schmitt 2008)

How could the people remain present within the constituted structure of the democratic state? In which way can the people perpetuate in the exercise of its unformed and decisive power? For Schmitt 'the natural form of the direct expression of a people's will is the assembled multitude's declaration of their consent or their disapproval, the acclamation' (Schmitt 2008, 131). The people can formulate and express its own decisional power only when assembled 
and sustaining or rejecting "publicly" the decisions of sovereign institutions. The popular assemblage in Greek democracies; the Roman Forum; the local government in a Swiss land: these are all examples of popular assembly. However, Schmitt is well aware that acclamations and assemblies are unknown to contemporary-liberal-constitutional regimes.

Quite surprisingly, especially in in light of his explicit aversion for democratic liberalism, Schmitt sustains that in modern democracy the public opinion is the form acclamations have taken. The possibility for the people to express and influence the decisional instances of given political state's institution, is channelled in the whole set of "parties" and "groups" - but also the press and the cinema industries - through which the popular sentiment can be channelled. What makes the public opinion suitable to be a form of acclamation is the fact that it is usually an 'unorganized form': as much as acclamations, Schmitt sustains that the public opinion 'can never be recognized legally and made official, and, in some sense, it remains uncontrolled' (Schmitt 2008, 275). The people, through the non-institutional medium of the public opinion can express its endorsement or disapproval. The public opinion represents, therefore, the timebomb of the formless constitution-making power of the people.

Carl Schmitt's speculation over the meaning of the role of the people as political author of its own institutional and constitutional life is probably one of the clearest attempts to keep the creational formless potential of the people present inside the border of the constituted order. It could be argued that Schmitt's critique of liberalism and his peculiar idea of plebiscitary-direct democracy makes of the necessary presence of the people in the stage of state's politics its main hallmark. However, despite the sharpness of his strategy, Schmitt's attempt to find a place for a non-mediated expression of the people's will is ultimately delusional (Rash 2014). The people, in fact, can absolve its political function of the constitutional order, only by dividing itself in formed and unformed people, and through its reduction to "public opinion". But this is tantamount to making the people disappears; since it is only through the mediation of specific entities - like parties, groups of interests, the press, etc. - that the people can exercise its decisional power.

Even if quite carefully crafted, Schmitt's theorisation of the unformed people as an always-present entity capable of having a decisive influence in political decisions in the form of public opinion, ultimately fails in his purpose. It is not clear, in fact, how something like a formless potential could express itself through the mediation of specific cultural, social and political agencies, without being in a way or another, affected by them. Indeed, if the history of the last century teaches us, the public opinion - and all the media through which it finds a channel of expression - is not spontaneous, let alone something unformed; rather it is a field of conquest and manipulation in which different political agendas and economic powers compete in giving it a favourable form. Consequently, also in Schmitt's concept of the state the people find itself ultimately excluded. 


\section{THE IDEA OF THE PEOPLE}

Within the dynamic of secularisation, which has characterised Western temporal powers in the last four centuries, the people replaced the image of the almighty God as the source of every legitimate power. Indeed, the distinction between constituent and constituted power, replicates the foundational dialectic between God's absolute and ordained power; where the first corresponds to the divine transcendent absolute power to create, re-create and change the mundane order, while the latter represents the perfect and immanent creation of God, with its self-standing natural laws. The people's creational potential - as much as God's absolute power - stands out as the transcendent mythical legitimation of constituted order. But in doing so, the people as the holder of constituent power remain relegated to the sphere of the transcendental; it represents the mythicalimage according to which mundane political powers are considered as legitimate.

But, when the "people" entered the political lexicon of modernity conveyed in the conceptual apparatus of the theory of the state and constitution, its ambiguous polysemy. In the idea of people singularity and plurality, the self and the other, nature and culture, nomos and physis, are separated, opposed and re-articulated in the same conceptual framework. For what we have seen so far, through the engagement with the thought of Agamben, Rousseau and Schmitt, it is possible to discern three semantic levels in which the concept of "people" could be displaced: i) the people as an historical and social entity, with common identity, language and traditions; ii) the people as a political agent, as the holder of the constituent power and as the source of the legitimacy of state's institutions; iii) the people as the mass of the excluded subjects, the marginalised classes of those who cannot take fully part to the political community.

When observed from the angle of the first two levels, the idea of people assumes a specific normative value. The political body of the people, in its concrete sociohistorical reality asks for its realisation as a community according to the coordinates of its presupposed image-identity. The people must institute itself, and to do so, it needs to have the consciousness of its own identity as a political agent. The people are in motion towards the constitution of its own idea. But this brings about a peculiar contradiction, which Agamben delineates in this way: the people 'is what always already is and yet must, nevertheless, be realized; it is the pure source of every identity but must, however, continually be redefined and purified' (Agamben 1998, 178). A people is subject to a continuous mechanism of constitution and redefinition, since its real referent never coincides with its own idea.

${ }^{7}$ Carl Schmitt recognises that the idea of the relationship between pouvoir constituant [constituent/constituting power] and pouvoir constitué [constituted power] finds its complete analogy, systematic and methodological, in the idea of a relation between natura naturans [nature nurturing/creating] and natura naturata [nature natured/created]. See: Schmitt 2014, 123. 
But the problem with the "constitution of a people" (Laclau 2005) is that it can never be operated positively. As soon as the category of the people is invoked, it begins to function as an exclusionary device, always in need of being defined both internally and externally. As we have seen above, the political logic of "the people" is the one of division. Therefore, by choosing the people as a privileged term for articulating the very idea of politics and community, modern thought internalised the necessity of the other - of the enemy (to use a term dear to Schmitt).

In light of what has been done in name of the people and the resurgence of post-fascist populist sentiments, the challenge for a critical political and legal imagination, is not to question the validity of the category of the "people", or to re-frame it in more progressive terms; perhaps the time has come for thinking a community completely detached from whatever idea of the people.

I would like to thank Eric Loefflad for the intellectual support and the helpful comments on an earlier version of the text.

\section{BIBLIOGRAPHY}

Agamben, Giorgio. 1998. Homo Sacer: Sovereign Power and Bare Life. Translated by Daniel Heller-Roazen. Stanford, CA: Stanford University Press.

Agamben, Giorgio. 2000. Means without End: Notes on Politics. Translated by Cesare Casarino, Vincenzo Binetti. Minneapolis-London: University of Minnesota Press.

Agamben, Giorgio. 2005. The Time That Remains: A Commentary on the Letter to the Romans. Translated by Patricia Dailey. Stanford, CA: Stanford University Press, 2005.

Agamben, Giorgio. 2015. Stasis. Civil War as a Political Paradigm. Translated by Nicolas Heron. Edinburgh: Edinburgh University Press.

Althusser, Louis. 2007. "Rousseau: The Social Contract". In Politics and History. 128-129. Translated by Ben Brewster. London: Verso.

Badiou, Alain. 2016. "Twenty-Four Notes on the Uses of the Word 'People"'. In What Is a People? 21-31. Edited by Alain Badiou, Pierre Bourdieu, Judith Butler, Georges Didi-Huberman, Sadri Khiari, Jacques Rancière. New York: Columbia University Press.

Canivez, Patrice. 2004. “Jean-Jacques Rousseau's Concept of People”. Philosophy \& Social Criticism 30(4): 393-412.

Cassin, Barbara. 2014. Dictionary of Untranslatables. A Philosophical Lexicon. Princeton: Princeton University Press.

Durantaye de la, Leland. 2009. Giorgio Agamben: A Critical Introduction. Stanford, CA: Stanford University Press.

Falk, Francesca. 2011. Eine gestische Geschichte der Grenzen: wie der Liberalismus an der Grenze an seine Grenze kommt. Munich: Fink.

Foucault, Michel. 2007. Security, Territory, Population. Lectures at the Collège de France 19971978. New York: Palgrave Macmillan.

Hardt, Michael. Antonio Negri. 2004. Multitude: War and Democracy in the Age of Empire. New York: Penguin.

Hobbes, Thomas. 1983. De Cive. Latin Version. Edited by Howard Warrender. Oxford: Clarendon Press. 
Jellinek, Georg. 1914. Allgemeine Staatslehre. Berlin: Häring

Laclau, Ernesto. 2005. On Populist Reason. London: Verso.

Manin, Bernard. 1997. The Principles of Representative Democracy. Cambridge: Cambridge University Press.

Mouffe, Chantal. Ernesto Laclau. 1986. Hegemony and Socialist Strategy. London: Verso.

Negri, Antonio. 1999. Insurgencies. Constituent Power and the Modern State. Translated by Maurizia Boscagli. Minneapolis: University of Minnesota Press.

Piasentier, Marco. Davide Tarizzo. 2016. “The Government of a Multitude': Hobbes on Political Subjectification". In The Routledge Handbook to Biopolitics. Prozorov. 36-49. Edited by Simona Rentea, Sergei Prozorov. London: Routledge.

Possenti, Vittorio. 1988. "Sul concetto di popolo: momenti della filosofia pubblica antica e moderna". Rivista di Filosofia Neo-Scolastica 80(3): 395-423.

Rash, William. 2014. "Carl Schmitt's Defence of Democracy". In The Oxford Handbook of Carl Schmitt. Edited by Jens Meierhenrich, Oliver Simons. Oxford: Oxford University Press.

Rousseau, Jean-Jacques. 2002. The Social Contract and the First and Second Discourses. Edited by Susan Dunn. New Heaven: Yale University Press.

Schmitt, Carl. 2005. Political Theology. Four Chapter on the Concept of Sovereignty. Translated by George Schwab. Chicago: The University of Chicago Press.

Schmitt, Carl. 2008. Constitutional Theory. Translation by Jeffery Seitzer. Durham: Duke University Press.

Schmitt, Carl. 2014. Dictatorship. Cambridge: Polity Press.

Sieyès, Emmanuel Joseph. 2003. Political Writings: Including the Debate Between Sieyès and Tom Paine in 1791. Indianapolis: Hackett Classics.

Virno, Paolo. 2004. A Grammar of the Multitude: For an Analysis of Contemporary Forms of Life. New York: Semiotext(e). 